\title{
PENDIDIKAN KARAKTER ANAK USIA DINI
}

Tin Rustini

\begin{abstract}
Abstrak
Pendidikan karakter bangsa pada intinya merupakan pendidikan yang mengembangkan nilai-nilai budaya dan karakter bangsa yang berasal dari pandangan hidup atau ideologi agama. Budaya dan nilai-nilai yang terumuskan dalam tujuan pendidikan nasional. Nilai-nilai dalam pendidikan karakter itu terdapat 18 buah antara lain yaitu: Agama, jujur, toleransi, disiplin, kerja keras, kreatif, mandiri, demokratis, rasa ingin tahu, semangat kebangsaan, cinta tanah air, menghargai prestasi, komunikatif, cinta damai,gemar membaca, peduli lingkungan, peduli sosial, dan tanggung jawab.

Nilai-nilai budaya dan karakter bangsa melalui pendidikan dikembangkan agar peserta didik dapat menerapkan nilai-nilai tersebut dalam kehidupan sehari-hari sebagi pribadi, anggota keluarga, masyarakat dan warga negara yang religius, nasionalis, produktif, kreatif dan inovatif. Secara teknis pendidikan karakter bangsa dimaknai sebagai proses internalisasi penghayatan nilai-nilai budaya karakter bangsa dan nilainilai luhur akhlak muliayang dilakukan peserta didik secara aktif.

Pendidikan karakter sangat perlu diberikan terhadap bangsa Indonesia sejak dini.Hal ini dikarenakan membentuk suatu paradigma dan karakteristik agar menjadi bangsa yang maju di dukung dengan moral yang baik. Pengembangan karakter yang terbaik adalah jika dimulai sejak dini. Hal ini terkait dengan kepercayaan bahwa "Jika kita gagal menjadi orang baik di usia dini, di usia dewasa kita akan menjadi orang yang bermasalah atau orang yang kurang beruntung dan beban bagi orang lainnya.
\end{abstract}

\section{Kata kunci : Pendidikan karakter dan anak usia dini}

\section{A. Pendidikan Karakter Anak Usia Dini}

Pada pendidikan anak usia dini sangat perlu untuk memperhatikan dan menerapkan pendidikan karakter demi masa depan anak - anak Indonesia yang lebih baik. Dengan pendidikan karakter itu diharapkan pula anak - anak tumbuh paripurna atau sempurna. Pada usia 0 - 6 tahun, pada periode ini otak anak sedang berkembang dengan sangat pesat. Mereka akan mampu menyerap dengan cepat segala sesuatu yang dilihat atau didengarnya. Tahun-tahun pertama kehidupan anak merupakan kurun waktu yang sangat penting dan kritis dalam hal tumbuh kembang fisik, mental, dan fsiko sosial, yang berjalan sedemikian cepatnya sehingga keberhasilan tahun-tahun pertama untuk sebagian besar menentukan hari depan anak. Pemerintah telah menunjukkan kemauan politiknya dalam pembangunan sumberdaya manusia sejak dini. Pendidikan anak usia dini 
merupakan penentu pembentukan karakter manusia Indonesia di dalam kehidupan berbangsa.

Pendidikan anak usia dini (PAUD) adalah jenjang pendidikan sebelum pendidikan dasar merupakan suatu upaya pembinaan yang ditujukan bagi anak sejak lahir sampai dengan usia 6 tahun. Yang dilakukan melalui simulasi atau rangsangan pendidikan untuk membantu pertumbuhan dan perkembangan jasmani rohani agar memiliki kesiapan dalam memasuki pendidikan lebih lanjut, yang diselenggarakan pada jalur formal, informal dan non formal. Pengertian karakter menurut pusat bahasa Depdiknas adalah bawaan, hati, jiwa, kepribadian, budi pekerti, perilaku, personalitas, sifat, tabiat, temperamen, watak. Adapun berkarakter adalah berkepribadian, berperilaku , bersipat, dan berwatak. Menurut Tadkiroatun Musfiroh (UNJ, 2008) karakter mengacu kepada serangkaian sikap, perilaku, motivasi, dan keterampilan. Karakter berasal dari bahasa Yunani yang berarti "to mark" atau menandai dan memfokuskan bagaimana mengaflikasikan nilai kebaikan dalam bentuk tindakan atau tingkah laku, sehingga orang yang tidak jujur, kejam, rakus, dan perilaku jelek lainnya dikatakan orang berkarakter jelek. Sebaliknya orang yang perilakunya sesuai dengan kaidah moral disebut dengan berkarakter mulia. Konsep pendidikan karakter dapat dilihat pada contoh karakter mulia yang berarti memiliki pengetahuan tentang potensi dirinya, yang ditandai dengan nilai nilai, seperti reflektif, percaya diri, rasional, logis, kritis, analitis, kreatif, dan inovatif, mandiri, hidup sehat, bertanggung jawab, cinta ilmu, sabar, berhati-hati, rela berkorban, pemberani, dapat dipercaya, jujur, menepati janji, adil, rendah hati, malu berbuat salah, perhati lembut , pemaap, setia, bekerja keras, tekun, ulet, gigih, teliti, berpikir positip, disiplin, ansisipatif, inisiatif, visioner, bersahaja, betrsemangat, dinamis, hemat efisisien, menghargai waktu, pengabdian, pengendalian diri, produktif, ramah ,estetis, sportif, tabah, terbuka tertib. Karakteristik adalah realisasi perkembangan positip sebagai individu (intelektual, emosional, sosial, etika, dan perilaku). Individu yang memiliki karakter baik atau unggul adalah seseorang yang berusaha melakukan hal-hal yang terbaik terhadap Tuhan YME, dirinya, sesama lingkungan, bangsa dan 
negara serta dunia Internasional pada umumnya dengan mengoptimalkan potensi pengetahuan dirinya disertai dengan kesadaran, emosi dan motovasinya.

\section{B. Pentingnya Pendidikan karakter Anak Usia Dini}

Pembentukan karakter merupakan salah satu tujuan Pendidikan nasional. Pasal 1 UUD Sisdiknas tahun 2003 menyatakan bahwa diantara tujuan pendidikan nasional adalah mengembangkan potensi peserta didik untuk memiliki kecerdasan, kepribadian, dan ahlak mulia.

Amanah UU Sisdiknas tahun 2003 bermaksud agar pendidikan tidak hanya membentuk insan Indonesia yang cerdas, namun juga kepribadian atau karakter, sehingga nantinya akan lahir generasi bangsa yang tumbuh dan berkembang dengan karakter yang bernapas nilai-nilai luhur bangsa serta agama. Selain itu, Undang-Undang No. 23 tahun 2002 tentang Perlindungan Anak dan Pasal 26 tentang Kewajiban \& Tanggung Jawab Orangtua dan Keluarga untuk Mengasuh, memelihara, mendidik dan melindungi anak serta menumbuhkembangkan anak sesuai dengan kemampuan, bakat dan minatnya.

Pendidikan bertujuan melahirkan insan cerdas dan berkarakter kuat itu, juga sejalan dengan pendapat Dr. Martin Luther King, Yakni : “Intelligence pus character... that is the goal of true educatio" (kecerdasan yang berkarakter adalah tujuan akhir pendidikan yang sebenarnya).

Memahami pendidikan karakter. Pendidikan karakter adalah pendidikan budi pekerti plus, yaitu pendidikan yang melibatkan aspek pengetahuan, perasaan, dan tindakan. Menurut Thomas Lickoma, tanpa ketiga aspek ini, maka pendidikan karakter tidak akan efektif.

Dengan pendidikan karakter yang diterapkan secara sistematis dan berkelanjutan, seorang anak akan menjadi cerdas emosinya, Kecerdasan emosi ini adalah bekal yang penting dalam mempersiapkan anak menyongsong masa depan, karena seseorang akan lebih mudah dan berhasil menghadapi segala macam tantangan kehidupan, termasuk tantangan untuk berhasil secara akademis.

Dorothy Law Nolte pernah menyatakan bahwa anak belajar dari kehidupan lingkungannya. Lengkapnya adalah: 
Jika anak dibesarkan dengan celaan, ia belajar memaki

Jika anak dibesarkan dengan permusuhan, ia belajar berkelahi

Jika anak dibesarkan dengan cemoohan, ia belajar rendah diri

Jika anak dibesarkan dengan penghinaan, ia belajar menyeasali diri

Jika anak dibesarkan dengan toleransi, ia belajar menahan diri

Jika anak dibesarkan dengan pujian, ia belajar menghargai

Jika anak dibesarkan dengan sebaik-baik perlakuan, ia belajar keadilan

Jika anak dibesarkan dengan rasa aman, ia belajar menaruh kepercayaan

Jika anak dibesarkan dengan dukungan, ia belajar menyenangi diri

Jika anak dibesarkan dengan kasih sayang dan persahabatan, ia belajar menemukan cinta dalam kehidupan

Dasar pendidikan karakter ini, sebaiknya dimulai di usia kanak - kanak atau yang biasa disebut oleh para ahli Psikologi sebagai usia emas (Golden Age), karena usia ini terbukti sangat menentukan kemampuan anak dalam mengembangkan potensinya. Hasil penelitian menunjukkan bahwa sekitar 50\% variabiitas kecerdasan orang dewasa sudah terjadi ketika anak berusia 4 tahun. Peningkatan 30\% berikutnya terjadi pada usia 8 tahun, dan $20 \%$ sisanya pada pertengahan atau akhir dasawarsa merupakan lingkungan pertama bagi pertumbuhan karakter anak.

Selain itu, Saat usia dini, lebih mudah membentuk karakter anak. Sebab, ia lebih cepat menyerap perilaku dari lingkungan sekitarnya. Pada usia ini, perkembangan mental berlangsung sangat cepat. Oleh karena itu, lingkungan yang baik akan membentuk karakter yang positif. Pengalaman anak pada tahun pertama kehidupannya sangat menentukan apakah ia akan mampu menghadapi tantangan dalam kehidupannya dan apakah ia akan menunjukkan semangat tinggi untuk belajar dan berhasil dalam pekerjaannya.

Namun bagi sebagian keluarga, barangkali proses pendidikan karakter yang sistematis di atas sangat sulit, terutama bagi sebagian orang tua yang terjebak dengan rutinitas yang padat. Karena itu seyogyanya pendidikan karakter juga perlu diberikan saat anak - anak masuk dalam lingkungan sekolah, terutama 
sejak play group dan taman kanak-kanak. Disinilah peran guru, yang dalam filosopi jawa disebut digugu dan ditiru, dipertaruhkan, karena guru adalah ujung tombak di kelas, yang berhadapan langsung dengan peserta didik.

\section{Dampak Pendidikan Karakter}

Akhir-akhir ini pendidikan karakter menjadi isue yang hangat dibicarakan. Apa sih dampak dari pendidikan karakter terhadap keberhasilan akademik? Beberapa penelitian bermunculan untuk menjawab pertanyaan ini. Sebagai hasil penelitian Dr Mavin Berkowitz dan University Of Missouri dalam buletin Character Educator, menunjukkan peningkatan motivasi siswa sekolah yang meraih prestasi akademik pada sekolah yang menerapkan pendidikan karakter, kela-kelas yang secara komprehensip terlibat dalam pendidikan karakter menunjukkan penurunan drastis pada perilaku negatif siswa yang dapat menghambat keberhasilan akademik.

Dengan pendidikan karakter seorang anak akan menjadi cerdas emosinya.Kecerdasan emosi adalah bekal terpenting dalam mempersiapkan anak menyongsong masa depan, karena dengannya seseorang akan dapat berhasil dalam menghadapi segala macam tantangan, termasuk tantangan untuk berhasil secara akademis.menurut Joseph Zins, et .al.2001) mengkompilasikan berbagai hasil penelitian tentang pengaruh positip kecerdasan emosi anak terhadap keberhasilan di sekolah. Dikatakan ada sederet faktor - faktor resiko yang disebutkan ternyata bukan terletak pada kecerdasan otak, tetapi pada karakter, yaitu, percaya diri, kemampuan bekerja sama, kemampuan bergaul, kemampuan berkonsentrasi, rasa empati dan kemampuan berkomunikasi. Demikian pula pendapat Daniel Goleman tentang keberhasilan seseorang dimasyarakat ternyata 80 \% dipengaruhi oleh kecerdasan emosi anak, dan hanya 20 \% ditentukan oleh kecerdasan otak (IQ). Anak- anak yang bermasalah dalam kecerdasan emosinya akan mengalami kesulitan belajar, bergaul tidak dapat mengontrol emosinya . Anak-anak yang bermasalah ini sudah dapat dilihat sejak usia pra sekolah. Dan kalau tidak ditangani akan terbawa sampai usia dewasa. Sebaliknya para remaja yang berkarakter atau mempunyai kecerdasan emosinya tinggi akan terhindar dari 
masala-masalah umum yang dihadapi oleh remaja seperti kenakalan, tawuran narkoba, mitras, perilaku seks bebas dan sebagainya.

\section{Membangun Karakter Anak Usia Dini}

Kunci sukses keberhasilan suatu Negara sangat ditentukan oleh sejauh mana masyarakat mempunyai karakter yang kondusif untuk maju yang disebut "modal social“ (social capital). Jadi, bukan ditentukan oleh banyaknya sumber daya alam atau banyaknya jumlah penduduk dan luas geoografisnya. Karakter yang berkualitas perlu dibentuk dan dibina sejak usia dini. Usia dini merupakan masa kritis bagi pembentukan karakter seseorang, penanaman moral melalui pendidikan karakter sedini mungkin kepada anak-anak adalah kunci utama membangun bangsa.

Banyak hal yang harus dilakukan untuk membangun karakter anak usia dini yang diharapkan dapat mengubah perilaku negatif ke positif. Pertama kurangi jumlah mata pelajaran berbasis kognitif dalam kurikulum-kurikulum pendidikan anak usia dini. Pendidikan intelektual (kognitif) yang berlebihan akan memicu pada ketidak seimbangan aspek-asepk perkembangannya.

Kedua, setelah dikurangi beberapa pelajaran kognitif, tambahkan materi pendidikan karakter. Materi pendidikan karakter tidak identik dengan mengasahkan kemampuan kognitif, tetapi pendidikan ini adalah mengarahkan pengasahan kemampuan afektif. Metode pembelajaran karakter ini dilakukan dengan cerita-cerita keteladan seperti kisah-kisah keteladan Nabi-nabi, sahabatsahabat nabi, pahlawan-pahlawan Islam, dunia, nasional ataupun lokal. Cara lain yang dianggap baik dilakukan adalah dengan contextual learning, yaitu dalam setiap pembelajaran anak-anak diberikan contoh kegiatan yang baik dengan langsung diperlihatkan dalam tindakan-tindakan seluruh pendidik dalam suatu lembaga pendidikan.

Membangun karakter, merupakan proses yang berlangsung seumur hidup. Anak-anak, akan tumbuh menjadi pribadi yang berkarakter jika ia tumbuh pada lingkungan yang berkarakter pula. Dengan begitu, fitrah setiap anak yang dilahirkan suci bisa berkembang optimal. Oleh karenanya ada tiga pihak yang 
mempunyai peran penting yaitu, keluarga, sekolah, dan komunitas. (Megawangi, 2003:23)

Pembentukan karakter ada tiga hal yang berlangsung secara terintegrasi. Pertama, anak mengerti baik dan buruk, mengerti tindakan apa yang harus diambil, mampu memberikan prioritas hal-hal yang baik. Kedua, mempunyai kecintaan terhadap kebajikan, dan membenci perbuatan buruk. Kecintaan ini merupakan obor atau semangat untuk berbuat kebajikan. Misalnya, anak tak mau mencuri, karena tahu mencuri itu buruk, ia tidak mau melakukannya karena mencintai kebajikan.

Ketiga, anak mampu melakukan kebajikan, dan terbiasa melakukannya. Lewat proses sembilan pilar karakter yang penting ditanamkan pada anak. Ia memulainya dari cinta Tuhan dan alam semesta beserta isinya; tanggung jawab, kedisiplinan, dan kemandirian; kejujuran; hormat dan santun; kasih sayang, kepedulian, dan kerja sama; percaya diri, kreatif, kerja keras, dan pantang menyerah; keadilan dan kepemimpinan; baik dan rendah hati; toleransi, cinta damai, dan persatuan.

Tujuan mengembangkan karakter adalah mendorong lahirnya anak-anak yang baik. Begitu tumbuh dalam karakter yang baik, anak-anak akan tumbuh dengan kapasitas dan komitmenya untuk melakukan berbagai hal yang terbaik dan melakukannya dengan benar, dan cenderung memiliki tujuan hidup sehingga tercipta karakter manusia yang kondusif untuk maju yang disebut "modal sosial“ (social capital) yang akan menjadi modal menuju keberhasilan suatu negara.

\section{E. Peran Guru dan Orang Tua dalam Pendidikan Karakter Anak Usia Dini}

Karakter terbentuk sebagai hasil pemahaman dari hubungan dengan diri sendiri, dengan lingkungan (hubungan sosial dan alam sekitar), dan hubungan dengan Tuhan YME (triangle relationship). Namun, pengembangan karakter anak yang paling banyak dipengaruhi oleh lingkungan terutama dari orangtua. Dalam pengembangan karakter anak, peranan orangtua dan guru sangatlah penting, terutama pada waktu anak usia dini. 
Banyak hal yang harus dilakukan oleh guru dan orang tua untuk mengambangkan karakter anak usia dini, berikut beberapa upaya yang dapat dilakukan oleh guru dan orangtua dalam membangun karakter anak usia dini:

1. Memperlakukan anak sesuai dengan karakteristik anak.

2. Tumbuhkan pemahaman positif pada diri anak sejak usia dini

3. Memenuhi kebutuhan dasar anak antara lain kebutuhan kasih sayang, pemberian makanan yang bergizi.

Biasakan anak bersosialisasi dan berinteraksi dengan lingkungan sekitar

5. Pola pendidikan guru dengan orangtua yang dilaksanakan baik dirumah dan di sekolah saling berkaitan.

6. Berikan dukungan dan penghargaan ketika anak menampilkan tingkah laku yang terpuji.

7. Berikan fasilitas lingkungan yang sesuai dengan usia perkembangannya.

8. Bersikap tegas, konsisten dan bertanggung jawab.

Selain itu, guru harus membuat aktivitas yang dapat membantu ketercapaian tujuan pembentukan karakter yang baik yang dapat dilakukan melalui kegiatan yang bernilai dan mengarah pada terangkatnya rasa keber-Tuhanan, penghargaan, cinta, tanggung-jawab, kedisiplinan, kemandirian, kejujuran, kerendah-hatian, kepedulian, kebahagiaan, kerjasama, percaya diri, kreatif, kerja keras, toleransi, kebebasan, kedamaian, dan rasa persatuan.

Bagaimana menciptakan aktivitas yang menyenangkan dalam penanaman nilai kepada anak usia dini? Beberapa yang dapat dilakukan yaitu:

1. Meningkatkan wawasan dan pentingnya mendidik anak dengan metode yang menyenangkan.

2. Memperdalam wawasan tentang pentingnya pendidikan nilai dan menerapkannya dalam proses yang menyenangkan.

3. Meningkatkan skill dan kreativitas guru anak usia dini, dengan aktivitas menggali ide, memilih bahan, merancang, mencipta dan memanfaatkan media pembelajaran anak berbasis nilai (karakter).

4. Mengeksplorasi potensi yang dimiliki guru pendidikan anak usia dini dalam menyediakan dan memanfaatkan sumber belajar bagi anak usia dini. 
5. Meningkatkan profesionalisme guru anak usia dini dengan membekali ketrampilan mengelola proses pembelajaran yang menyenangkan.

\section{F. Kesimpulan}

1. Pendidikan karakter sebaiknya diberikan sejak usia dini, sebab pada usia - 0 sampai 6 tahun merupakan usia emas di mana 80 \% kecerdasan otak anak menentukan kecerdasan usia dewasa dan selebihnya $20 \%$ kecerdasan otak diperoleh pada usia dewasa

2. Hasil penelitian menunjukkan anak dengan pendidikan karakter dapat terhindar dari masalah - masalah yang tidak diharapkan dan motivasi belajarnya ada peningkatan.

\section{DAFTAR PUSTAKA}

Sumarmo, Utari. 2011. Pembelajaran Matematika Berbasis Pendidikan Karakter. Cimahi: Prosiding Seminar Nasional Pendidikan Matematika.

Wahyudin. 2011. Membangun Karakter Melalui Pendidikan Matematika yang Berkualitas. Cimahi: Prosiding Seminar Nasional Pendidikan Matematika. http://id.shvoong.com/writing-and-speaking/presenting/2166222-pentingnyapendidikan-karakter-sejak-anak/\#ixzz1jOqEFAeA

http://paud.unnes.ac.id/index.php?option=com_content \&view=article\&id=6: membangun-karakter-melalui-pendidikan-sejak-usia-dini-\&catid=9:depan http://edukasi.kompasiana.com/2012/01/12/pentingnya-alat-permainanedukatif-untuk-penanaman-karakter-pada-anak-usia-dini/

\section{BIODATA PENULIS}

Tin Rustini adalah dosen pada Universitas Pendidikan Indonesia dpk. UPI Kampus Cibiru Bandung. Penulis menyelesaikan pendidikan jenjang magister (S-2) pada Program Studi Pendidikan IPS SD, Sekolah Pascasarjana, Universitas Pendidikan Indonesia. 